\title{
Understanding local and scientific knowledge about flooding adaptations in low-lying areas of Central Vietnam
}

\author{
Hiểu biết về kiến thức bản địa và kiến thức khoa học trong việc thich ứng với lũ lụt ở vùng thấp \\ trũng miền Trung Việt Nam
}

TRAN, Huynh Bao Chau*; UBUKATA, Fumikazu²

'University of Economics, Hue University, 99 Ho Dac Di street, Hue city, Vietnam; ${ }^{2}$ Okayama University, 3-1-1 Tsushima-naka, Kita-ku, Japan

\begin{abstract}
This research focuses on clarifying the local and scientific knowledge about flooding adaptations, the interaction between local knowledge and scientific information in the low-lying area of Central Vietnam is analyzed. Data was obtained using three techniques including: semi-structured interviews, direct observation and household surveys. Responses indicate that the villagers have accumulated and inherited this type of knowledge in their society for a long time. The level of local knowledge is affected by gender, occupation and house location. This implies that the villagers' social roles and their everyday interactions with the natural environment have nurtured an accumulated local knowledge. Scientific information is provided by the National Committee for Flood and Storm Control and National Center for Hydrometeorology Prediction. It contains information regarding disaster type, intensity, risk level and directions. The information is transferred to local people through mass media, social networks and official documents. However, local people are credulous toward scientific information given by the state. It was found that many villagers are not likely to follow the official guideline, especially the villagers with a high level of local knowledge.
\end{abstract}

Nghiên cứu tập trung làm rõ kiến thức bản địa và khoa học về thích ứng lũ lụt cũng như mối tương tác của chúng ở vùng trũng thấp miền Trung Việt Nam. Dữ liệu được thu thập bằng cách sử dụng kết hợp ba phương pháp bao gồm phỏng vấn bán cấu trúc, quan sát trực tiếp và khảo sát hộ gia đình. Các kết quả nghiên cứu chỉ ra rằng người dân đã tích lũy và kế thừa kiến thức bản địa từ xã hội của họ trong một thời gian dài. Mức độ kiến thức bản địa bị ảnh hưởng bởi giới tính, nghề nghiệp và vị trí nhà ở. Vai trò xã hội và những tương tác hàng ngày của người dân với môi trường tự nhiên đã nuôi dưỡng và tích lũy kiến thức bản địa. Thông tin khoa học được cung cấp bởi Ủy ban Phòng chống lụt bão Quốc gia và Trung tâm Dự báo Khi tượng Thủy văn Quốc gia. Các thông tin về loại thiên tai, cường độ, mức độ rủi ro và hướng chỉ dẫn được thông báo. Thông tin này được chuyển đến người dân thông qua các phương tiện thông tin đại chúng, mạng xã hội và các văn bản chính thức. Tuy nhiên, người dân địa phương chủ quan trước những thông tin khoa học do cơ quan nhà nước đưa ra. Nhiều người dân không tuân theo các hướng dẫn chính thức của chính quyền địa phương, đặc biệt là những người có mức độ kiến thức bản địa được đánh giá cao.

Keywords: local knowledge; scientific information; flooding; adaptation; low-lying of Central Vietnam

\section{Introduction}

Floods are extreme events caused by environmental factors that injure humans and damage property, especially in low-lying areas (Doocy, 2013). Therefore, adaptations are necessary to mitigate the catastrophic damages caused by flooding. Moreover, flooding is an ambivalent problem when perceived as a disaster and resource (Ehlert, 2007). Flooding control do not ensure a sustainable development and could bring negative effects. Approaches, arranged into three groups, have been conducted as responses to flooding: engineering, scientific and traditional approaches (Fabiyi \& Oloukoi, 2013). Engineering and scientific approaches require more investment and the participation of local governments, communities and other organizations. Scientific knowledge is useful but rarely brings efficiency to local adaptations (Lebel, 2013). In some areas, these approaches have overcome their capacity for deployment. Contrary to the first two approaches, traditional approaches are viewed as sustainable for development (Chikaire \& Nnadi, 2011). Theoretically, local knowledge has been built from experience, tested over centuries of use and adapted to the local culture and environment; it is embedded in from experience and ritual, always dynamic and changing (FAO, 2004).

Local knowledge is the human capital which is clarified not only as "folk knowledge" but also as "human experience, accumulated from long periods of time to adapt and change the natural and social environment, 
serving the material and spiritual interests for themselves" (Ngo, 2009). As stated by Thieken et al., (2007), unlike scientific knowledge (that is similar everywhere), local knowledge varies from area to area (Agriculture and Forestry Research and Development Center for Mountainous Region, 2014). Local knowledge is also expressed according the skills, experience and insights of people (UNESCO, 2017).

Concerning the relationship between local knowledge and adaptation, the latter is considered as the adjustments in ecological, social or economic systems to respond to the actual or expected climatic stimuli and their effects or impacts. It also refers to changes in processes, practices and structures either to moderate potential damages or to benefit from climate change (IPCC, 2001). Adaptation also means the adjustments in a system's behavior and the characteristics that enhance its ability to cope with external stresses. Adaptation does not occur instantaneously; a system requires time to realize its adaptive capacity (Brooks, 2003). By definition, adaptation is understood as a socio-cognitive-behavioral process, used as adaptive behavior for the changes in cognition (Grothmann \& Patt 2003). Moreover, adaptive capacity is the potential or ability of a system, region or community to adapt to climate change impacts (IPCC, 2001).

This research focuses on clarifying the local and scientific knowledge about flooding adaptation and the interaction between the local knowledge with scientific information. In Tanzania, where the role of local knowledge is identified for adaptations to climate change, the local power relations and the interaction with government strategies is also considered (Naess, 2013). Comparing three environmental management projects in United Kingdom, Solomon Islands and Australia, the processes and mechanisms available for integrating different types of knowledge for environmental management was evaluated (Raymond et al., 2010). The Thua Thien Hue province is located in Central Vietnam, an area that has undergone several effects from storms and flooding.

Local knowledge about flooding is integrated into the local preparedness for disaster mitigation when it describes disaster predictions through animal or plants behavior in the coastal area (Tran et al., 2012). However, local knowledge is informal, personal or tacit while scientific knowledge refers to the explicit knowledge of formal methods concerning different positions on validity and reliability (Raymond et al., 2010). Under the development of scientific technology, many projects or policies have been conducted in large areas without considering local knowledge. Therefore, it is necessary to explore the villagers' behavior when scientific information is issued.

\section{Material and methods}

\subsection{The study site}

The Thua Thien Hue province is located in a long and narrow area with a diversified topography. This area has a transitional climatic zone between north and south, usually experiencing the storm effects. The Quang An commune belongs to the Quang Dien district. As one of the low-lying areas of the Thua Thien Hue province, it was selected to conduct the survey (Figure 1).

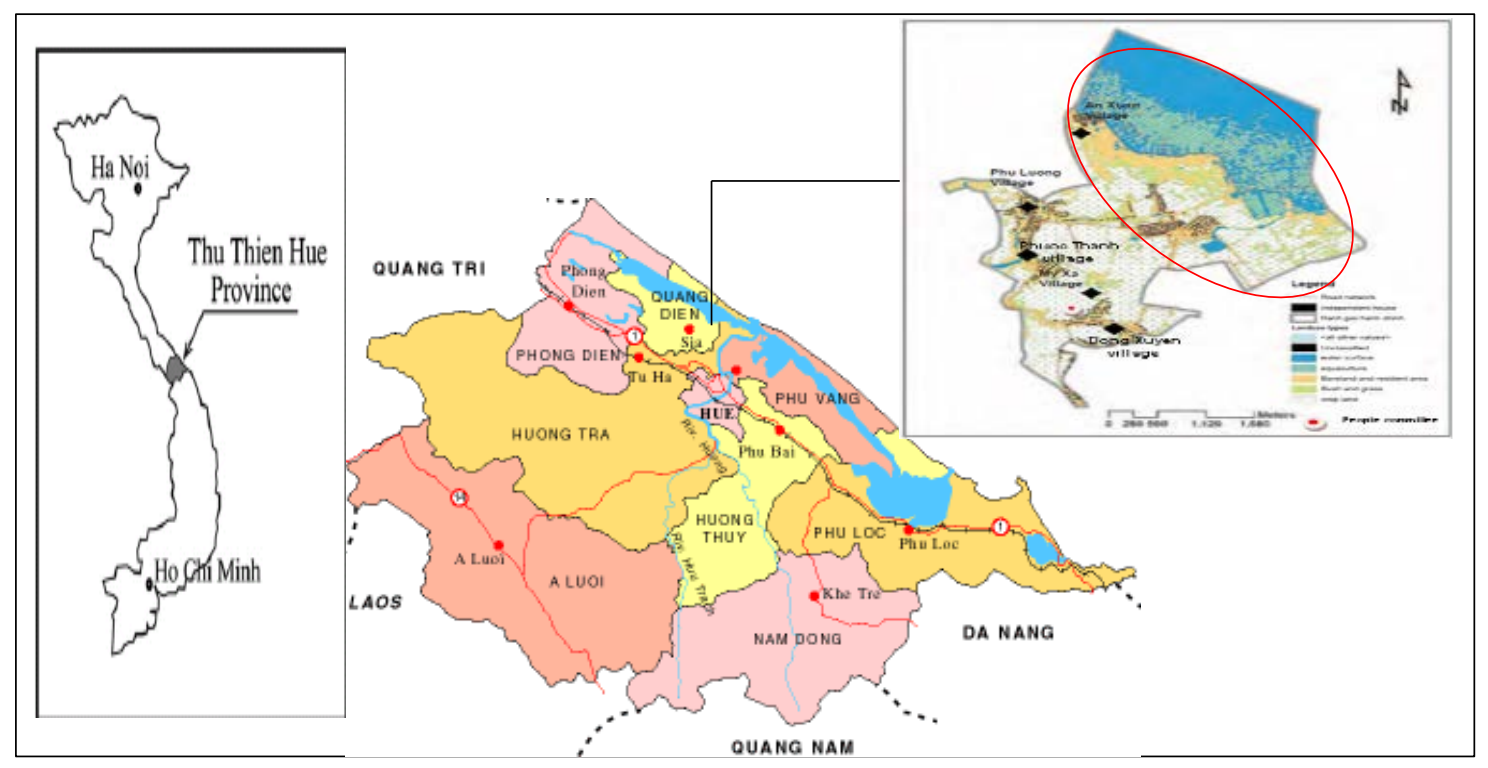

Figure 1. Location map of An Xuan village, Quang An commune

(Source: Ministry of Natural Resource and Environment, 2016) 
The Quang Dien district is located in the northern area of the province, about $20 \mathrm{~km}$ far from the Hue city, with a population of 82,813 inhabitants settled in 16,329 ha. This district consists of 10 communes including the Quang An, Quang Thanh, Quang Phuoc, Quang Tho, Quang Vinh, Quang Thai, Quang Loi, Quang Ngan, Quang Cong, Quang Phu communes and the Sia town; the Quang An commune is one of the low-laying areas.

The Quang An commune had a total area of 1,187.09 ha and 10,966 people living in 2,827 households according data from 2016. There are 5 villages: An Xuan, Dong Xuyen, Phuoc Thanh, Phu Luong, My Xa); the An Xuan village has accounted for nearly $50 \%$ total area of the commune (593.52 ha) with 1,337 households. Total population of the An Xuan village is 5,284 inhabitants. This village is located in the periphery of the Tam Giang lagoon and downstream of the Bo river, one of the main rivers in the Thua Thien Hue province. By its geographic conditions, this area is frequently inundated during heavy rains.

\subsection{Data collection and analysis}

\subsubsection{Data collection}

This research was based on field surveys to understand the current local knowledge and scientific information in flooding adaptation. The pilot survey was conducted during 2016 in order to collect secondary data such as natural conditions, socio-economic conditions and the current flood damage situation in the Quang An commune. Due to results from official documents and the recommendation of the Quang An commune authority, the An Xuan village was selected to conduct the main survey.

Participatory Rural Appraisal (PRA) was used to collect information applying three techniques. Firstly, a semistructured questionnaire was used to interview 10 keyinformants in the An Xuan village, those having experience, heads of the community and the elderly. In this way, the in-depth information about the village history, local knowledge, behavior and social network with flooding was collected. Secondly, a layout of the village was drawn through direct observation. The collected information regarding flooding experience and flooding reaction of the local people was verified. Thirdly, based on the information from in-depth interviews and direct observation, the structure questionnaire was designed.

The stratified sampling approach was used to select households for survey, from the richest to poorest, in the study site. There were three suburbs in the An Xuan village where the head was required to select 15 households from the richest to the poorest. Five households were missed to obtain data through the survey. The demographic characteristics of 40 surveyed households are described in table 1.
Table 1. Demographic characteristics of household survey

\begin{tabular}{|c|c|c|c|}
\hline No. & Household characteristics & Unit & Results \\
\hline \multirow[t]{3}{*}{1} & Respondents & number & 40 \\
\hline & Male & $\%$ & 70 \\
\hline & Female & $\%$ & 30 \\
\hline \multirow[t]{6}{*}{2} & Education level & & \\
\hline & Illiterate & $\%$ & 10 \\
\hline & Primary school & $\%$ & 47.5 \\
\hline & Secondary school & $\%$ & 30 \\
\hline & High school & $\%$ & 10 \\
\hline & College, university & $\%$ & 2.5 \\
\hline \multirow[t]{4}{*}{3} & Age & & \\
\hline & 30 - 45 years old & $\%$ & 22.5 \\
\hline & 46 - 60 years old & $\%$ & 47.5 \\
\hline & Upper 60 years old & $\%$ & 30 \\
\hline
\end{tabular}

(Source: Author's survey, 2016)

\subsubsection{Data analysis}

Qualitative and quantitative analysis was applied to address the above objectives. The collected data from semi-structured interviews and household surveys were synthesized and analyzed to clarify the local knowledge in flooding adaptation. The efficiency of scientific information and local government units were referred to react with the flooding.

Chi-square analysis was used to test the association between two nominal variables: local knowledge level and demographic characteristics. After the analysis, the main factors affecting the local knowledge of the surveyed households were identified. Moreover, the relationship between local knowledge and flooding adaptation was expressed.

\section{Results}

\subsection{Flooding situation in Thua Thien Hue province}

In the Thua Thien Hue province, flooding damages, from the end of the 19th and the early 20th century, have been recorded by the Provincial Committee for Flood and Storm Control (CFSC). From 1999 to 2014, flooding has occurred annually causing different damage. The most memorable events are the storm in 1983, the big flood in 1985, the historic flood in 1999 and the floods in 2004, 2008, 2009. According to the Chairman of the Quang An People Committee, the flood impacts in this area are reported as following: "In the history flood 1999, three persons died in the Quang An commune, 70 - 80\% of the local property was drifted away in flood water. Houses were inundated to the roof and local people did not have any food and clean water for many days. In 2007, a flood made one death and one injured person, 52 households needed to be evacuated. 
In September 2009, the total damage, recorded by the local government, was approximately 256 million VND and one fatality. In November 2010, a flood claimed the life of a pupil and damages of about 2.5 billion VND. From 2013 to 2019, flooding has decreased in frequency, as well as in intensity, due to a hydropower station in the upstream river. The flooding damage mainly focuses on agriculture and aquaculture production".
In this study, the bottom-up approach is applied to identify whether the local community understands the flooding situation or not. To achieve this result, local people needed to answer the question "What do you think about the flooding characteristics over the past ten years?" Through the observation of surveyed households, the overview evaluation of local people is expressed in Figure 2.

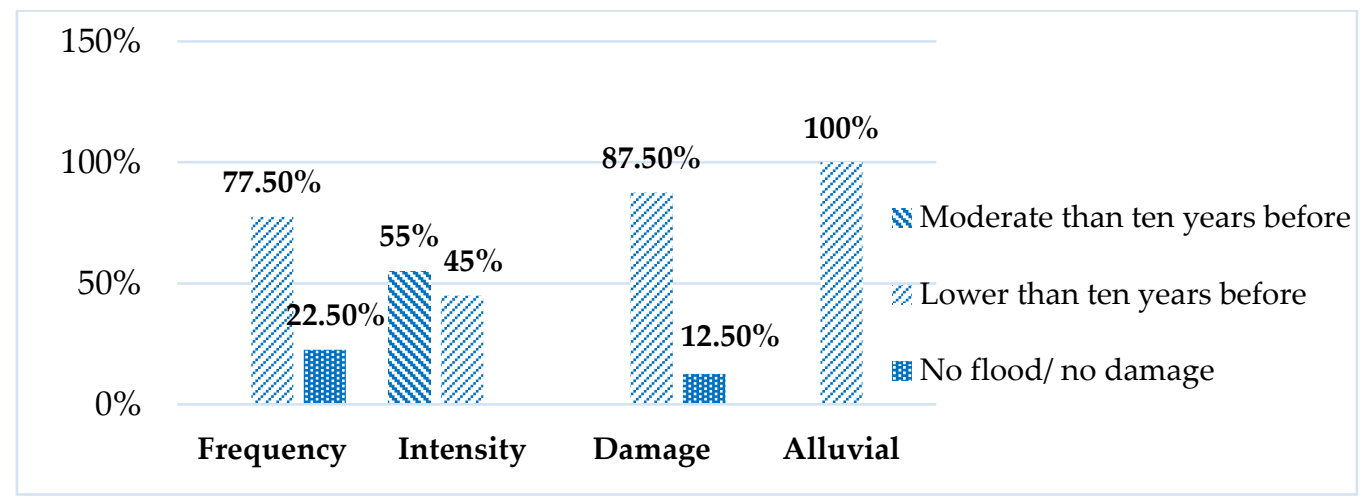

Figure 2. Household perception of flooding trend over the past ten years (2006 - 2016)

(Source: Author's survey, 2016)

Figure 2 shows that local people had identified the changing of flooding characteristics over the past ten years. In 40 surveyed households, $77.5 \%$ of the respondents perceived that the frequency of flooding is lower than ten years ago while $22.5 \%$ perceived that flooding does not happen recently. When the frequency is changed, the intensity is also affected. A 55\% of the respondents agreed with "the intensity is moderate compared to the last ten years"; a $45 \%$ of the respondents said that "the intensity is lower than ten years ago". Corresponding with the decreasing of frequency and intensity, the flooding damage is also reduced with an agreement of $87.5 \%$ of the respondents. When the flooding trend changes, the alluvial is also influenced. 100\% of surveyed households perceived that "alluvial is lower than ten years before".

\subsection{Local knowledge of surveyed households in the Quang An commune}

\subsubsection{Local knowledge in adapting}

Local knowledge contains the observatory experience, anticipation and reaction towards flooding. Observations the Thua Thien Hue province show that flooding usually starts from August to October with storms occurring from October to November of the lunar calendar. During this time, the low-lying areas receive water from the upstream locations. In October, the flooding or water level increase can occur on the third, thirteenth and twenty-third day. Every month, the sea level is high when the full moon appears. The villagers, based on natural phenomena, anticipate the weather; for instance, when the clouds are eastward and northward crowded, flooding will come. If the cloud is westward and southward crowded, it forecasts the thundershower. When thunderstorms events occur during 2 or 3 continuous nights, it means that flooding will occur. Flooding is also forecasted when a freshwater fish (Crucian carps) is in the breeding season. Thirdly, flooding reaction is formed from practical experience. Flooding is created by heavy rain or storm. To react to flooding, local people behave as a local proverb states: "Storm sits at the low, flood climbs up the high position". This means that villagers hide below the cellar in case of a storm. In case of flooding, they utilize the free space between the living area and the roof to build a "Tra"- the free space in the attic (Figure 3).

Based on the house structure, the wood is arranged to make the living space for people as well as for storing the properties in case of flooding. Moreover, local people had adapted agriculture production from observing the flood season. It is safe if the paddy is cultivated after the 22 of December of the normal calendar (Winter Solstice) with long-day seed. In Summer - Autumn season, a short-day seed is used to harvest at the end of July. After harvesting, paddy is contained in 50 kilograms bags and is moved to "Tra" or high places to prevent flooding damages.

Before the historic flood of 1999, it was used to put paddy into wooden boxes. In the historic flood of 1999, most of the local people had big damages because the water level increased very quickly. There was not enough time for rescuing the paddy as well as other properties. Adjustments are also applied in aquaculture production; it starts at the beginning of February and finishes at the end of July of the lunar calendar to reduce the flood damage. A polyculture production is applied to have the harvest around the year. 

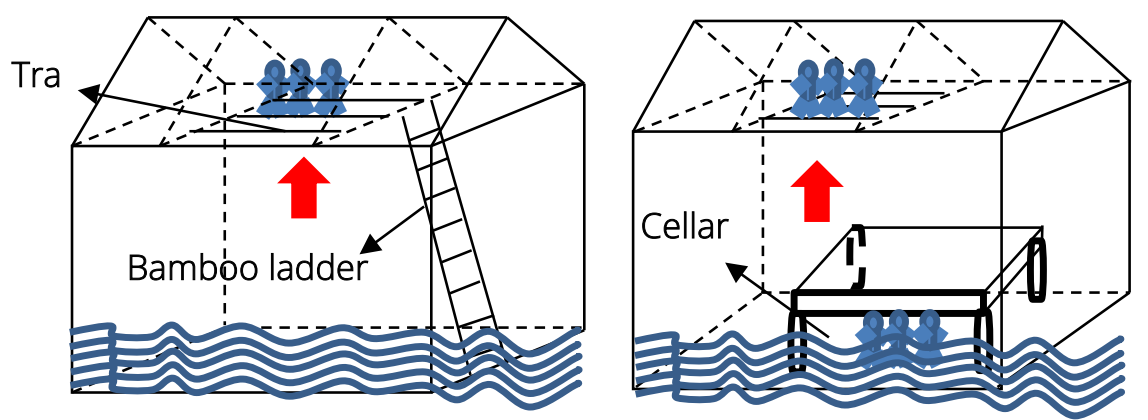

Figure 3. Flood reaction (left) and storm reaction (right) based on the local knowledge

(Source: Author's survey, 2016)

\subsubsection{Local knowledge classification of surveyed households}

After living in this area for a long time, the population have a basic knowledge about its location. Adjacent of the Tam Giang lagoon, this area usually suffers flooding impacts. After the end of the production season, they stay at home to prepare for the flood season. Nowadays, when communication is developed, local people have a very easy approach to scientific information. The weather forecast on television or the commune broadcast system is used to update inhabitants on weather information. From this, they will have full preparation for the flooding season and abnormal phenomena as well. It is supposed that the older people become, the high level of local knowledge they have. It does not apply for all situations, for instance, when some elderly people are too old to remember the information or apply these practices as a habit.
Surveyed households were asked three questions regarding: flooding time, traditional experience to forecast and flooding reaction. Three levels were used to express the local knowledge of each household. Interviewees were evaluated with a low level if they perceive flooding as normal event; These households rely on the weather forecast to update the weather information and to know the way to react to flooding. The interviewees, who know clearly about flood season and have the preparedness for the flooding reaction, are classified as moderate level. Similarly, a high level is assigned if the interviewees can anticipate a flooding event through natural phenomena. It is hypothesized that the local knowledge level depends on gender, occupation, house location, and house type. Divided into three levels, the number of households, as well as the demographic characteristic of each level, is determined. The results are shown in Table 2.

Table 2. Demographic characteristic of each local knowledge level

\begin{tabular}{|c|c|c|c|c|c|}
\hline \multirow[t]{2}{*}{ Demographic characteristics } & \multicolumn{4}{|c|}{ Local knowledge level } & \multirow{2}{*}{$\begin{array}{l}\text { Sig. } \\
\text { (2-sided) }\end{array}$} \\
\hline & High & Moderate & Low & Total & \\
\hline \multicolumn{6}{|l|}{ Gender } \\
\hline Male & $7(25 \%)$ & $15(53.6 \%)$ & $6(21.4 \%)$ & $28(100 \%)$ & \multirow[t]{2}{*}{$0.001 *$} \\
\hline Female & 0 & $2(16.7 \%)$ & $10(83.3 \%)$ & $12(100 \%)$ & \\
\hline \multicolumn{6}{|l|}{ Occupation } \\
\hline Agriculture & $2(6.9 \%)$ & $11(37.9 \%)$ & $16(55.2 \%)$ & $29(100 \%)$ & \multirow[t]{2}{*}{$0.001 *$} \\
\hline Aquaculture & $5(45.5 \%)$ & $6(54.5 \%)$ & 0 & $11(100 \%)$ & \\
\hline \multicolumn{6}{|c|}{ House location compared with river, canal or lagoon } \\
\hline Near & $7(26.9 \%)$ & $9(34.6 \%)$ & $10(38.5 \%)$ & $26(100 \%)$ & \multirow[t]{2}{*}{$0.086 * \star$} \\
\hline Far & 0 & $8(57.1 \%)$ & $6(42.9 \%)$ & $14(100 \%)$ & \\
\hline \multicolumn{6}{|l|}{ House type } \\
\hline Permanent & 0 & $1(33.3 \%)$ & $2(67.7 \%)$ & $3(100 \%)$ & \multirow[t]{3}{*}{0.781} \\
\hline Semi-permanent & $5(21.8 \%)$ & $9(39.1 \%)$ & $9(39.1 \%)$ & $23(100 \%)$ & \\
\hline Temporary & $2(14.3 \%)$ & $7(50 \%)$ & 5 (35.7\%) & $14(100 \%)$ & \\
\hline
\end{tabular}

Note: *, ** denote the statistical significance at the $5 \%$ and $10 \%$ level respectively. $N=40$ households. (Source: Author's survey, 2016) 
Local knowledge of men was classified at a higher level than women since men have a higher responsibility for family activities. With power and flexibility skills, men can solve the heavy things and give out the final decision for the family. The psychology of women is dependent on husbands. In the survey, 7 households with high local knowledge level are men. The strong relationship between local knowledge level and gender was identified with 95\% significance level.

This research focuses on two main occupations in which agriculture accounts for $72.5 \%$ (29 households) and aquaculture is $27.5 \%$ (11 households). Flooding creates a negative impact on these activities because their production depends on natural conditions. The result of the survey expresses that no one of the 11 aquaculture farmers were evaluated with a low local knowledge level. Occupation is the second factor that affects the establishment of local knowledge. Furthermore, this relationship between occupation and local knowledge level is confirmed with a $95 \%$ of significance.

With the geographical condition of the village, not only aquaculture farmers but also agriculture farmers live nearby the river or the lagoon with a high risk to be inundated by flooding. In this research, if the distance from surveyed households to a river, canal or lagoon is equal or lower than 50 meters, they are arranged into a near group. The result shows that 7 households that have high local knowledge are located nearby the river, canal or lagoon. Therefore, the third factor contributing to the building the local knowledge is the house location with a 90\% of significance. The house type is expressed by the household economy and used as a tool for flooding reaction. The number of permanent houses mainly belongs to a moderate and low level while high local knowledge groups possess a semi-permanent and temporary house. It can be understood that it is difficult to build a permanent house in the rural area. It means that local knowledge level is not influenced by house type. Through table 2, we can conclude that a high local knowledge is related to men, living nearby the river, canal or lagoon and working in aquaculture production.

\subsection{Scientific knowledge in flooding adaptation}

\subsubsection{The weather information}

In Vietnam, the information of disaster and risk is provided by the National CFCS and National Center for Hydrometeorology Prediction. The management and exchange of weather information starts from the National CFSC and the National Center for Hydrometeorology ending at the households (Tran, 2010). Through yearly observation of natural phenomena, the National Center for Hydrometeorology forecasts all disasters that would happen in Vietnam. The scientific information contains the type of disaster, intensity, weather forecast, early warning, risk levels and its direction. The National CFSC has the responsibility of delivering the weather information to local people and to conduct the preparedness for rescue and relief activities.

Based on scientific information, Vietnam's government, local government and the local people define the actions against flooding in order to minimize the damage. In correspondence to each province, the standards of flooding warning are adjusted to be suitable for each region. Since the Huong, the Bo and the Ta Trach are the main river basins in the Thua Thien Hue province, they are used as the standard for other small rivers. There are four flooding warning levels in Vietnam, particularly in the Thua Thien Hue province. Local government units are established to support local people in disaster management. Through this system, weather information is transferred in two ways in which mass media is evaluated as the fastest and more convenient. By the development of communication media, households easily approach weather information by television, radio or the internet. Another way is by official documents, a system which belongs to the administration mechanism. However, it takes more time to be transferred through several departments or organizations before being delivered to local people.

Table 3. Flood warning levels in the main rivers of Thua Thien Hue province

\begin{tabular}{|c|c|c|c|c|}
\hline Main rivers & Flood warning level I & Flood warning level II & $\begin{array}{l}\text { Flood warning level } \\
\text { III }\end{array}$ & $\begin{array}{l}\text { Flood warning } \\
\text { level III+ }\end{array}$ \\
\hline Bo & $1.5 \mathrm{~m}$ & $3.0 \mathrm{~m}$ & $4.5 \mathrm{~m}$ & $>4.5 \mathrm{~m}$ \\
\hline Huong & $1.0 \mathrm{~m}$ & $2.0 \mathrm{~m}$ & $3.5 \mathrm{~m}$ & $>3.5 \mathrm{~m}$ \\
\hline Ta Trach & $59 \mathrm{~m}$ & $61 \mathrm{~m}$ & $63 \mathrm{~m}$ & $>63 \mathrm{~m}$ \\
\hline $\begin{array}{l}\text { Description of } \\
\text { warning level }\end{array}$ & $\begin{array}{l}\text { Water level increases in all rivers. } \\
\text { Riverside and the low-lying areas are } \\
\text { threatened. }\end{array}$ & $\begin{array}{l}\text { Dangerous status. The even } \\
\text { and flat areas are inundated, } \\
\text { except for the town and city. }\end{array}$ & Very dangerous & Urgent status \\
\hline Direction & \multicolumn{2}{|c|}{ Check, review the low-lying areas for going the evacuation } & Take the evacuation & \\
\hline
\end{tabular}

(Source: The Social Republic of Vietnam, 2020. 


\subsubsection{Adaptive capacity of local government units and local organizations}

Scientific technology is also applied for the transferring of warning information to local people. When received from the National Center for Hydrometeorology information, the telecommunication operators are required to send warning messages to all phone numbers in the Thua Thien Hue province. HueS is a software, published in 2019, for the announcing of information in. However, this program requires that local people have a smartphone and to be connected to internet. This limits the access of elderly people in this rural area.

Nowadays, a detailed weather is forecasted before 24 or 48 hours for the specific area. Local people prepare themselves to deal with floods or storm. Based on scientific information, local government units are prepared to deal with the flooding season, conducting the direction to be taken on a higher level. The operation of the broadcasting system is checked to ensure a proper communication. Local people are asked to go to safe places such as common houses or permanent houses in the local area to ensure human life. Schools, temples and common houses are used as public shelters when having a disaster.

The Quang An commune is one of the most prone areas to flooding in the Thua Thien Hue province. Located in a low-lying area, this commune has put many efforts to reduce flooding damages by enhancing the basic infrastructure and establishing the Committee for Flood and Storm Control. The people's committee has already focused on infrastructures such as streets, schools, markets, spillways, etc. to enhance the capacity adaptation. This area received support from the local government and the Non-Government Organizations in disaster management. First, Nordic Assistance to Vietnam (NAV) supported this village for five years since 1985. This organization helped poor people to build houses able to respond to floods and storms. Second, The Japan International Cooperation Agency (IICA) supported this village for three years since 2012. This organization supported the evacuation of houses and schools and by providing pumps and life jackets for conducting rescue activities; it also carried out training courses about climate change adaptation. The evacuation house of JICA (2012), with a high of 2.5 meters, is used for flood prevention; however, it is not useful in case of a storm because it is located in an empty area.

The Luxembourg organization supported this village during 2 periods (2007 - 2010 and 2013 - 2017) by building infrastructure such as streets and a drainage system. In 2014, a Luxembourg committee visited the An Xuan village to take the survey. In 2016, the construction of the Con Bai canal and the Ba Cua drain started, being finished at the end of 2017.

\subsection{Households' behavior toward the official guideline}

The changing of flooding in corresponding with frequency, intensity, damage and alluvial over the past ten years is observed by local people (Figure 2). Based on the scientific knowledge of the state agencies, the local government developed plans, including calls, for the evacuation of the people into shelters. It was found, however, that many villagers are not likely to follow this official guideline. The result of household behavior is synthesized in Table 4.

\section{Table 4. Households' behavior toward the official guideline}

\begin{tabular}{llllll} 
& \multicolumn{2}{l}{ Local knowledge level } & & Sig. \\
\cline { 2 - 5 } Households' behavior & High & Moderate & Low & Total & $(2$-sided $)$ \\
\hline Follow the official guideline & 0 & $3(23.1 \%)$ & $10(76.9 \%)$ & $13(100 \%)$ & $0.003^{*}$ \\
Unfollow the official guideline & $7(25.9 \%)$ & $14(51.9 \%)$ & $6(22.2 \%)$ & $27(100 \%)$ & \\
\hline
\end{tabular}

Note: * denote the statistical significance at the $5 \%$ level. $N=40$ households. (Source: Author's survey, 2016)

From 40 surveyed households, only 13 follow the official guideline. It means that mainly people with a low local knowledge level follows the official guideline. They are people who, based on the weather forecast, have the preparedness for the flooding. Therefore, they are easy to follow the official guideline. On the contrary, the unfollowing group (27 households) is arranged from the high to low local knowledge level. It is important that most households in moderate and high local knowledge levels belong to this group. This group contains the people having experience with observation, anticipation and reaction to flooding. Of course, they have the full preparedness for flooding and will base on themselves to react with flooding.
Furthermore, there were 6 households of low local knowledge levels also belonging to this group. Although their experience and their preparedness are not the same as high and moderate level, their behavior follows certain habits such as moving to their parents or neighbor's house. These activities had been done before and they still continue.

\section{Discussion}

According to household behavior towards the official guideline, a problem is referred to "Why local people do not follow the official guideline?" On the contrary, local 
people will follow the official guideline to happen the disaster in developed countries.

Whatever the local government units are, they have the same role and we will consider their efficiency and the actual activities of local government units. In Japan, when a tsunami is expected to cause coastal damage, the Japan Meteorological Agency (JMA) issues a tsunami warning within 2-3 minutes after the earthquake. The announcements of estimated height and arrival time of the tsunami are issued and transmitted immediately to disaster management organizations and media outlets, and further forwarded to residents and maritime vessels (Japan Government, 2015).

By the accuracy of information as well as the combination of local government units, residents can find a safe shelter before the tsunami happens. By combining modern technology, the development of basic infrastructure and organizational structure, the efficiency of scientific information is enhanced while the damage is reduced. Although local government units provide support for the local people in this study site, there are some limited problems.

First, the early warning information is issued in a large area by public media, social networks, and official documents. However, each person will have a different perception of the warning. Second, local government units only have full preparation in the flooding season. If a flood happens suddenly, it is difficult to manage immediately. Moreover, the equipment and infrastructure for rescue and relief activities are inadequate. Local government units do not have solutions to protect the citizens' property after they go to the evacuation places. The quality and quantity of evacuation places do not ensure the safety neither the living conditions.

Each person has the responsibility in protecting the property. Through previous experiences, they do not go to the evacuation places, which are prepared by local government units. Instead of taking the evacuation, they stay at home or go to their parents or neighbors' houses. These places are considered the safest, a convenient and optimal option for them when flooding happens. Vietnamese folk has the sentence "While there is life, there is hope" to express their attitude. They will not give up until there is no other choice. So, they want to stay at home. When a dangerous situation happens, they will destroy the roof and call the neighbor or the local community for help. Households who have a boat will move to the boat in case of immense flooding or a dangerous situation. This finding illustrates that the local knowledge's role is determined by the interaction between informal and formal institutions (Naess, 2013).

This investigation highlights that local knowledge has the predominant role in decision making. It is similar to the findings from agricultural farmers in a rural village of Mexico (Rivero-Romero et al., 2016). The indigenous, or local knowledge, is the key to climate change mitigation and adaptation (Chikaire \& Nnadi, 2011). Moreover, the observation and interaction of local people or communities with the environment and its change is important in flood management and preparedness activities (Kamarulzaman et al., 2015). In the survey, most households mention the problem: "If they do not understand the weather forecast, they will ask their neighbor". In Vietnam, particularly in the Thua Thien Hue province, since the local government units are not enough for helping people, it is essential to provide scientific knowledge to local people. In the rural area of Central Vietnam, where local people mainly believe in themselves, it is necessary to perform meetings to share scientific knowledge.

Through the transferring of scientific knowledge to local people, their adaptive capacity will be gradually increased. In this way, new local knowledge can be established through creativity and innovativeness mechanisms as well as by contact with other knowledge systems (Warren, 1991). Local knowledge or scientific information is useful when helping local people to react to flooding.

\section{Conclusions}

This research clarifies the local knowledge in flooding adaptation and the interaction between local knowledge and scientific information. First, the status of local knowledge related to flooding adaptation is identified. It indicates that the villagers have accumulated and inherited this type of knowledge in their society for a long time. Second, this research found out that the accumulation of local knowledge varied from person to person. It also identified the factors that affected the local knowledge level that the villagers hold: gender, occupation and house location. This implies that the villagers' social relationships and their everyday interactions with their natural environment have nurtured local knowledge accumulation. Third, this research also found a strong relationship between local knowledge and flooding adaptation. It is noticeable that villagers with a high local knowledge level did not follow the official guideline. Local people are reluctant towards scientific information given by the state.

\section{References}

[1] Agriculture and Forestry Research and Development Center for Mountainous Region, A. (2014). Indigenous Knowledge Identidication and use in community-based adaptation practices.

[2] Brooks, N. (2003). Vulnerability, Risk and Adaptation: A Conceptual Framework. Tyndall Centre for Climate Change Research, University of East Anglia.

[3] Chikaire, J. and Nnadi, F. N. (2011). Indigenous Knowledge for Climate Change Mitigation and Adaptation in Agriculture in sub-saharan Africa., Report and opinion 3(5): 32 - 44 
[4] Doocy, S., Daniels, A., Murray, S., \& Kirsch, T. D. (2013). The human impact of floods: a historical review of events 1980-2009 and systematic literature review. PLoS currents, 5, ecurrents.dis. f4deb457904936b07c09daa98ee8171a.

[5] Ehlert, J. (2007). - Local and Global Knowledge on Flood Management - How Can Local Knowledge Contribute to Resilience in the Mekong Delta, Vietnam.

[6] Fabiyi, O. O., Oloukoi, J. (2013). Indigenous Knowledge System and Local Adaptation Strategies to Flooding in Coastal Rural Communities of Nigeria. Indigenous Social Development, 2(1), 1-19.

[7] FAO. (2004). What Is Local Knowledge? Retrieved from http://www.fao.org/3/y5610e/y5610e01.htm\#bm1

[8] Grothmann, T., Patt, A. (2003). Adaptive capacity and human cognition. Prepared for the presentation at the Open Meeting of the Global Environmental Change Research Community, Montreal, Canada.

[9] IPCC. (2001). Adaptation to Climate Change in the Context of Sustainable Development and Equity. Working Group II: Impacts, Adaptation and Vulnerability, 8(9), 880-912.

[10] Japan Government. (2015). Disaster management in Japan / 日本の災害対策 |, 52. Retrieved from http://www.preventionweb.net/publications/view/43 589

[11] Kamarulzaman, N. H., Vaiappuri, S. A. K., Ismail, N. A., Mydin, M. A. O. (2015). Local knowledge of preparedness: current phenomena to future action. Journal Technology, 5, 85-89.

[12] Lebel, L. (2013). Local knowledge and adaptation to climate change in natural resource-based societies of the Asia-Pacific. Mitigation and Adaptation Strategies for Global Change, 18(7), 1057-1076.

[13] Naess, L. O. (2013). The role of local knowledge in adaptation to climate change. Wiley Interdisciplinary Reviews: Climate Change, 4(2), 99-106.

[14] Ngo, T. D. (2009). Local knowledge and development. Retrieved from http://www.vanhoahoc.vn/nghien-cuu/tai-lieu-tiengnuoc-ngoai/vietnamese-culture/1434-ngo-duc-thinhlocal-knowledge-and-development.html (In Vietnamese).

[15] Raymond, C. M., Fazey, I., Reed, M. S., Stringer, L. C., Robinson, G. M., Evely, A. C. (2010). Integrating local and scientific knowledge for environmental management. Journal of Environmental Management, 91(8), 1766-1777.

[16] Rivero-Romero, A. D., Moreno-Calles, A. I., Casas, A., Castillo, A., Camou-Guerrero, A. (2016). Traditional climate knowledge: a case study in a peasant community of Tlaxcala, Mexico. Journal of Ethnobiology and Ethnomedicine, 12(1), 1-11.

[17] Social Republic of Vietnam. (2020). Degree 05/2020/QD-Ttg of Prime Minister. Retrieved from http://vanban.chinhphu.vn/portal/page/portal/chinh phu/hethongvanban?class_id=1\&mode=detail\&docu ment_id=199001 (In Vietnamese).

[18] Thieken, A. H., Kreibich, H., Müller, M., Merz, B. (2007). Coping with floods: Preparedness, response and recovery of flood-affected residents in Germany in 2002. Hydrological Sciences Journal, 52(5), 10161037.

[19] Tran, D. T., leru, T., Hirohide, K. (2012). Living with typhoon and flood disasters: a case study in Huong Phong commune, Tam Giang lagoon area, Central Vietnam. An Environmental Journal for the Local Community, 6, 85-96.

[20] Tran, P. (2010). Adaptation behaviors of communities and households to extreme climate events in Quang Nam Province, Viet Nam: Towards a set of possible adaptation measures. EEPSEA Research Reports (Vol. 9).

[21] United Nations Educational, Scientific and Cultural Organizations (UNESCO). (2017). Local and indigenous Knowledge system (LINKS). Retrieved from https://en.unesco.org/links

[22] Warren, D. M. (1991). Using indigenous knowledge in agricultural development. World Bank Discussion Papers (Vol. 127). 